\title{
The Concept of Information Poverty and How to Measure it in the Latin American Context
}

\author{
Gover Barja \\ UNIVERSIDAD CATÓLICA BOLIVIANA \\ Björn-Sören Gigler \\ LONDON SCHOOL OF ECONOMICS
}

\begin{abstract}
The construction of the information society must be complemented with propoor vision and policies. For this reason, this paper defines the concept of information and communication poverty, introduces the criteria of poverty line location for its identification, and suggests computation for the economic cost of reaching such a line for its aggregate measurement. In this process, the structural and technological restrictions faced by a society are acknowledged, and the way they affect and are affected by the concept of information and communication poverty is discussed. This research study examines these issues conceptually, in order to contribute to the study regarding magnitude, depth and characteristics of information and communication poverty, as well as to identify some of its implications for drafting public policies.
\end{abstract}




\section{Introduction}

An important consequence of globalization is that growth of small open economies increasingly dependent on their internal and external competitiveness. As a consequence public policy in Latin America tends to focus primarily on improving the competitiveness of its economies and of the region. However, this economic growth paradigm based on pro-competitiveness policies does not guarantee, by itself, a solution to the multiple challenges of reducing poverty. For this reason, pro-growth policies must be complemented by pro-poor policies.

This paper is based on the hypothesis that an information society based on progrowth policies must be complemented by pro-poor policies. This work focuses only on the aspect related to the need to develop pro-poor policies that accompany, complement and strengthen the process of constructing an information society.

In order to develop these pro-poor policies, it is necessary to carefully define the meaning of information and communication poverty, its relation to the construction of the information society, its connection to poverty-reducing policies and its contribution to development. This issue is developed in the second section of this document. The third section develops criteria to define poverty in terms of a person's lack of information and communication capabilities, and identifies criteria to measure and evaluate aggregate information poverty. These criteria are the main contribution of this paper. In a manner similarly to literature on poverty, the reasons for its measurement are to inform society on its magnitude and depth, its causes and consequences, as well as to contribute to the drafting of pro-poor public policies. This section also acknowledges a society's technological and structural constraints regarding the way they affect and are affected by information and communication poverty. The fourth section presents conclusions and some implications.

\section{What is Poverty and what is Information and Communication Poverty}

\section{DEVELOPMENT, POVERTY AND INEQUALITY}

In its broad definition, development is the process of expansion of human freedoms. Sen's point of view (2000) establishes that the expansion of freedoms is development's means and ultimate goal. Among the freedoms highlighted by Sen as development means are: political freedom ${ }^{1}$, economic facilities ${ }^{2}$, social opportuni-

\footnotetext{
${ }^{1}$ People's opportunities to determine who should govern and under which principles, freedom to evaluate and criticize authorities, freedom of expression, right to dialogue, to oppose, to criticize, to vote, to choose among political parties, to be involved in Legislative and Executive elections.

${ }^{2}$ An individual's opportunities to use economic resources with the purpose of consumption, production or exchange. The economic ownership of a person depends on the possession of resources, use availability, exchange conditions and its distribution.
} 
ties $^{3}$, transparency guarantees ${ }^{4}$, protective security ${ }^{5}$ and the significant and complementary relationships among them. These freedoms strengthen an individual's capability; poverty is, from this point of view, the lack of basic capabilities. Thus, an adequate multidimensional assessment of the improvement observed on the standard of living of the poor must analyze their achievements and obtained capabilities.

In practice, due to information restrictions and the long-term impact on poverty, assessments conducted on poverty reduction have been focused on more limited variables, such as income or expenditure patterns of the poor. Traditional methodologies are based on defining a set of criteria to identify the poor and assessing aggregate poverty.

For example, Ravallion (2000) defines the absolute criterion of one dollar and two dollars per day, as a line to identify the poor. Then, he measures aggregate poverty by the ratio of individuals below that line, as well as the sum of distances to that line as the poverty gap. Dollar and Kraay (2000) apply the income of the poorest fifth as a relative criterion to identify the poor. They then measure aggregate poverty according to per-capita income in this group. The World Bank Institute's experience (Online, 2005) indicates that the consumption expenditure criterion $^{6}$ may be more appropriate for the identification of the poor than the income criterion. It suggests establishing a poverty line based on a basic food expenditure method that takes into account the minimum calorie intake needed by a person per day, or the basic needs basket method, which includes expenditures on food and non-food basic items; aggregate poverty is then measured according to the FGT Index ${ }^{7}$ or the SST Index ${ }^{8}$.

Although monetary income/consumption has the benefit of being quantifiable, it can only be considered an approximation of an individual's welfare, since it does not make any reference to the quality of life, from Sen's point of view. Other approaches are based on resource availability, represented by pragmatic variables

\footnotetext{
${ }^{3}$ It refers to the way a society organizes itself to provide education, health and social services, which contribute to an effective participation on political and economic activities.

${ }^{4}$ It refers to the fact that social interaction is based on the basic assumption of confidence. Such expected confidence guarantees an open and clear attitude among involved parties, contributing to prevent corruption, financial irresponsibility and obscure agreements.

${ }^{5}$ It refers to a vulnerable situation people may be experiencing, which requires safety nets, unemployment benefits, income for the needy, emergency funds.

${ }^{6}$ Usually making adjustments for durable goods, housing services, size and composition of home.

${ }^{7}$ Foster, Greer and Thorbecke (1984) introduced a set of parametric poverty measurements which generates three poverty indicators: ratio of poor, poverty gap and poverty severity.

${ }^{8}$ Sen, Shorrocks and Thon introduced an index computed according to the indicators of ratio of poor, digital divide and Gini's coefficient.
} 
such as income per capita, individual available income, or by primary goods, a more theoretical but broader variable ${ }^{9}$. Robeyns (2004) is rather conciliatory when suggesting that these different approaches (monetary, resource and capability) should be viewed as complementary in terms of poverty measurement, poverty analysis (micro or macro) and relevance, depending on the type of poverty analysis.

The work An Asset-Based Approach to the Analysis of Poverty, by Attanasio and Székely (1999), derived from the approaches mentioned above, states that the structural causes of poverty depend mainly on:

- Ownership of income-earning assets, which can be physical assets (housing and basic services), human assets (health, education) or social assets (social networks and rules).

- $\quad$ Rate of asset-use, since the higher the use, the higher the income (employment opportunity, gender, credit access).

Based on this approach, the authors conclude that social policy should aim at generating income by increasing household assets, creating opportunities for productive asset use, and increasing their market prices.

In this context of varying conceptual approaches to poverty, a specific question arises regarding the causes and characteristics of poverty in Latin America ${ }^{10}$. Székely (2001) points out that poverty in Latin America is not mainly due to a lack of resources to fulfill basic needs, but to income distribution inequality. The question inferred from this statement is: What is the reason for an inadequate income distribution in Latin America? According to Attanasio and Székely (2001), approximately one third of the inequality is based on personal variables such as education level, age, gender, region, occupation, economic activity, etc. The other two thirds are based on economic structural aspects, which are repeated at all economic levels: city, municipality, state and region.

These observations on inequality are of particular interest when considering that the concept of development is based on the traditional economic growth paradigm. Dollar and Kraay (2000) point out that economic growth also benefits the poor in a one-to-one relationship; thus, specific policies for poverty reduction are not justified. In contrast, Bourguignon (2001) shows that growth elasticity of poverty is a decreasing function of the development level obtained by an economy, as well as a decreasing function of the inequality level of relative income.

In addition, Lora, Pagés, Panizza and Stein (2004) conclude that the structural

\footnotetext{
${ }^{9}$ Also called Rawlsian goods: those every rational person would wish: income, wealth, opportunities and social base of self-respect.

${ }^{10}$ There is vast literature on poverty, more than the exposed here, which reflects a permanent state of debate.
} 
reforms may not have improved poverty and inequality conditions, since they did not attack their causes, namely: the lack of access by the poor to credit and to assets which increase their productivity. They also point out that poverty and inequality reduction policies should focus on releasing the poor's growth potential, facilitating their acquisition of productive assets by ensuring such assets during times of crisis and increasing their access. Székely (2001) also concludes that economic growth, by itself, does not solve the poverty problem. For this reason, pro-growth policies must be complemented and strengthened by pro-poor policies. These policies should address the structural causes of poverty ${ }^{11}$, and should be large-scale in order to have a significant impact on the society (social policy) ${ }^{12}$, contributing in this way to longterm growth ${ }^{13}$. A key question in the information society context is: What role does access to information and communication through ICT play within the structural causes of poverty? As many authors have emphasized (Kenny, 2003; Gigler, 2001 and 2005; McNamara, 2000 and 2003), the present discussion about the 'digital divide' focuses on the analysis of the access level of different groups (i.e. the connectivity level of women or minority groups in a society) and does not reflect the reasons that cause the existing gap. For this reason, this paper focuses on the definition of information and communication poverty, to attain a better comprehension of the key factors that determine if a society is prepared to take advantage of ICT for economic development and poverty reduction.

\section{CONCEPT OF INFORMATION AND COMMUNICATION POVERTY}

There is no need to develop an independent theory for the information society; in turn, the existing theory should be applied to clarify a particular aspect of poverty and development. From this discussion we can foresee that the construction of the information society would naturally be based on the pro-growth approach, as reflected by the pro-competitiveness indicators published by the World Economic Forum (2004). This paper argues, however, that the creation of the information society should be complemented by a pro-poor approach to avoid the increase in inequalities and social exclusion, specifically in Latin America, a region with high levels of social and economic inequalities and low levels of economic and human development.

It may also be suggested that, in the broadest sense, the expansion of human freedoms must also be the means and ultimate goal in the construction of the information society, as a way of contributing to development. These freedoms will

\footnotetext{
${ }^{11}$ These pro-poor policies could not be relief or protection programs for the poor during times of crisis, or safety nets, as these are circumstantial and do not attack the causes of poverty. Usually the programs focused on income work over consequences without changing causes.

${ }^{12}$ Programs with a limited impact could not be used either, even if they attacked structural causes of poverty, since they have a limited impact by focusing on reduced groups of society.
} 
strengthen the individuals' capability to participate in the information society and therefore the communication and information poverty is a lack of the basic capabilities needed to participate in the information society.

As Gigler (2005) has pointed out, information is not only a source of knowledge, but also a special source of advancement of economic, social, political, and cultural freedoms. It can be said that access to and use of information and communications are essential conditions for development, as they affect every dimension of life. Likewise, information and communication poverty can only be one dimension of poverty, but affects all other dimensions. For that reason its effective reduction is interdependent on the other dimensions.

We must add to the discussion the origin of the information society, which results from the continuous technological revolution observed in the field of the information and communication technologies. However, as Easterly (2003) highlights, nothing happens when technology is available but the incentives to use it are not present. In particular, Easterly indicates the need of intervention to compensate the disincentives to technological innovation ${ }^{14}$.

\section{Measurement of Information and Communication Poverty}

\section{POVERTY LINE}

The need for advancement in freedoms $\Delta \mathrm{L}^{\mathrm{i}}$ must be the result of the difference between the desired demand of freedoms $\mathrm{L}_{1}{ }_{1}$ and the current freedoms achieved $\mathrm{L}_{0}$ for each kind $\mathrm{i}: \Delta \mathrm{L}^{\mathrm{i}}=\mathrm{L}_{1}^{\mathrm{i}}-\mathrm{L}_{0}^{\mathrm{i}}$. The requirement of expansion of each kind of freedom is not the same, as some of them may be more desired than others according to the circumstances.

This approach highlights $\mathrm{L}_{0}$, as it is what a society has achieved and, therefore, the minimum required for all its geographic locations ${ }^{15}$. From this point of view, the geographic locations ${ }^{16}$ suffering from a lack of freedoms $\mathrm{PL}^{\mathrm{j}}$ are those that have not

\footnotetext{
${ }^{13}$ Pro-poor policies must be consistent with pro-growth policies, and not oppose them.

${ }^{14}$ Disincentives refer to problems of: unsuitability and obsolescence; existence of a process of creative destruction; need of technological substitution and reorganization of the productive activity; creation of winners and losers, and resistance from the latter; attitude of the society towards the innovations within a democratic environment; shortage of factors complementary to new technologies; uncertainty of the technological direction of the future, and its economic result; attraction of new innovations towards geographical concentrations.

${ }^{15}$ From here on, the location is taken as the unit of analysis, since universal access will continue to be the main goal to achieve in the middle term in most of the countries in Latin America.

${ }^{16}$ From here on, poor geographic locations will be understood as rural locations with less than 1000 inhabitants (it could be considered even with less than 5000 inhabitants), based on observations made in Latin America. Poor neighborhoods in urban areas are not included, since they pose a different problem, one of universal service, where the household is the unit of analysis.
} 
yet reached $L_{0}^{i}$, but a lower level of $\mathrm{L}_{0}$ for each location $\mathrm{j}$ : $P \mathrm{~L}^{\mathrm{j}}=\mathrm{L}_{0} \mathrm{i}-\mathrm{L}_{0}$. From this abstract point of view, there also exists a minimal level of information and communication $\mathrm{IC}_{0}^{\mathrm{i}}$, consistent with the minimum freedoms attained by a society $\mathrm{L}_{0}{ }_{0}$. In addition, there should be a minimum capability level $\mathrm{CAP}_{0}{ }_{0}$, consistent with the minimum level of information and communication $\mathrm{IC}_{0}{ }_{0}$. Access to information may be instrumental for identifying a person's desired demand of freedoms. Usually, the poorer are not aware of the opportunities available for improving their standard of living. In this sense, the minimum capabilities of information and communication also play a 'catalytic' role for the advancement of the freedoms in other aspects of the life of the poor. Therefore, we arrive at the definition of information and communication poverty ICPj, as the deprivation of basic capabilities to participate in the information society:

$$
\mathrm{ICP}^{\mathrm{j}}=\mathrm{CAP}_{0}^{\mathrm{i}}-\mathrm{CAP}_{0}^{\mathrm{ij}}
$$

The minimum capabilities $\mathrm{CAP}_{0}{ }_{0}$ define the information and communication poverty line, and the observed capabilities $\mathrm{CAP}^{\mathrm{ij}}{ }_{0}$ for each geographic location $\mathrm{j}$ establish the distance to the poverty line.

This poverty line implies the minimum capability required to participate in the information society, which has three components summarized in Table 1. The geographic location must have a set of minimum assets related to ICT, basic health care and education, social capital and productive capability. It should be able to exchange (receive and provide) a minimum of transparent information about political, institutional, economic processes (including those of production, commercialization and income distribution), and about social protection mechanisms. It must be able to communicate, through the analysis and a minimum level of exchange of ideas about political, institutional, technological and economic processes as well as social protection mechanisms ${ }^{17}$. In addition, the three-component set of minimum capabilities to own assets and exchange information and communication must be consistent with each other ${ }^{18}$.

\footnotetext{
${ }^{17}$ This approach is also consistent with a phenomenon examined by the literature on poverty, which refers to the relationship between the ability to obtain income and the ability to use such income (Sen, 1995). In our case, one issue is the problem resulting from inequalities and a lack of basic capabilities to participate in the information society, and another issue, though related, is the problem caused by inequalities which prevent transforming such participation in the information society into new capabilities.

${ }^{18}$ Another way of understanding the difference between exchange of information and exchange of ideas is the difference between stock of knowledge and increase of such stock.
} 
Table 1: Guidelines on Required Interrelated Capabilities

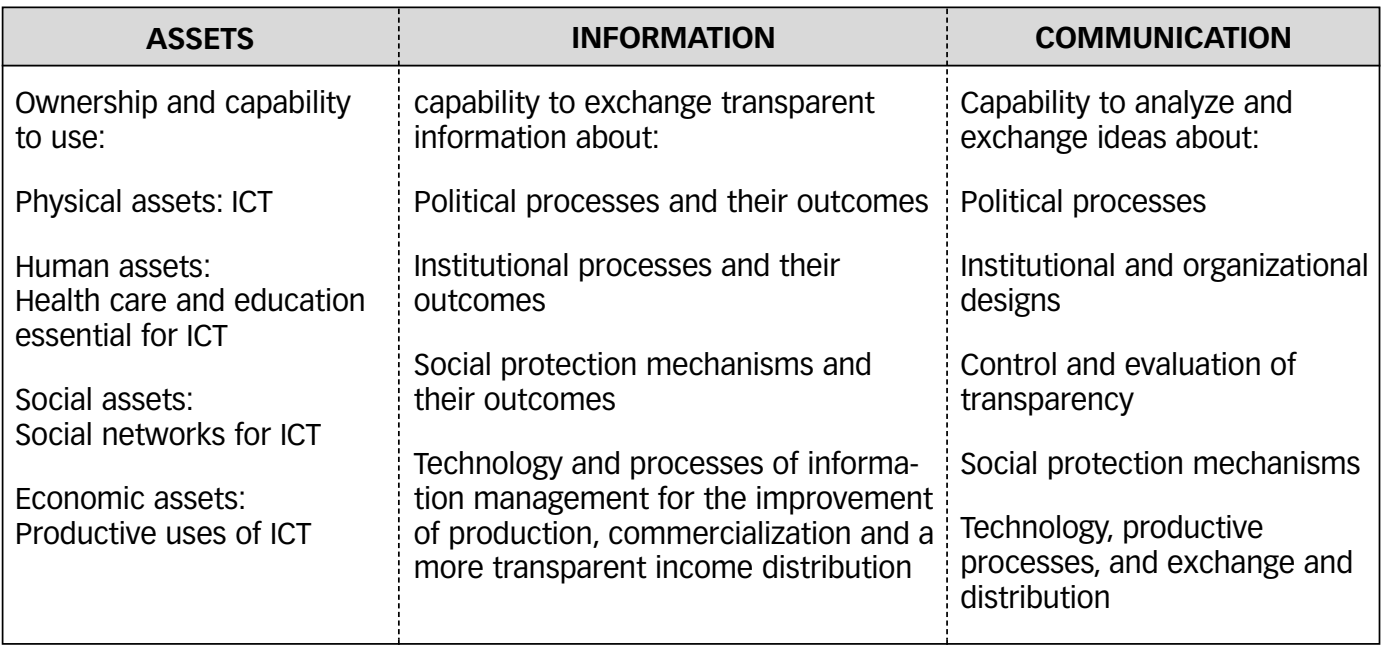

According to this approach, it is not possible to identify the poverty line under a single criterion. It is necessary to consider several criteria at the same time to generate a global indicator. Individual and aggregate indicators published by the World Economic Forum (2004) and by Orbicom (2003) are examples. However, such indicators are characterized by their bias towards indicators that only measure the accumulation of assets ${ }^{19}$, corresponding to the first column of Table 1 . On the other hand, the capabilities approach goes beyond the accumulation of assets. In order to obtain information exchange capabilities, training and experiences in generating and using information on the topics listed in the second column of Table 1 are required. To obtain capabilities to exchange ideas, training and experiences in the creation and use of innovations on the topics listed in the third column of Table 1 are required.

How is it possible to obtain the minimum global indicator that represents the poverty line? In practical terms, the identification of a reference location for the country or geographical zone under analysis is recommended. This geographic location is characterized by participating in the information society, regardless of having the lowest possible set of indicators, in other words, it represents the poverty line location. The selection of such a geographic location would be arbitrary, as there will be different interpretations regarding the meaning of participation in the information society and the meaning of minimum indicators ${ }^{20}$ for a specific loca-

\footnotetext{
${ }^{19}$ Physical, human and environmental assets of business, government and not poor individuals, indicated by country, in the case of the World Economic Forum. Physical and human assets and the intensity of its use, indicated by country, in the case of Orbicom. Even though the latter includes an interesting discussion on the need of knowledge and capabilities to understand and use the available information. Several of these ideas are included in Table 2.

${ }^{20}$ The poverty line location might be an observable or an abstract location.
} 
tion. This extent of arbitrariness is similar to the one frequently observed in the definition of access or universal service goals. As Cherry and Wildman (1999) point out, this is a consequence of the fact that the goal definition is the product of a sociopolitical process, which responds to a specific set of temporary economic and technological possibilities. In our case, the poverty line location reflects the goal of universal access to the information society; a goal that must be defined through a participative political process. This last point is particularly relevant since societies will express their concerns about what the real priorities for poverty reduction are. For instance, the issue will come up whether or not efforts should first concentrate on health care, education, and basic services or on the access to new information and communication technologies. Literature on participatory processes (Chambers 1997; Nelson and Wright, 1995) highlights a methodology of participation, and the implications these processes have on power relationships between the dominant class and the excluded and poor sectors of a society. In the context of information poverty, it is necessary to highlight that the poor have to identify, through a collaborative process, the opportunities and challenges that ICT can offer to improve their standard of living, i.e. the access to basic services as education and health care.

\section{AGGREGATE MEASUREMENT OF POVERTY}

The purpose of choosing a poverty line location is to measure the distance from other locations to that reference line. This implies that individual and global indicators must be generated for every location studied. A foreseeable problem is the array of characteristics and differences among locations and their environment, which would not allow for a comparison among them. A natural solution to this problem is the monetary appreciation of distances, by calculating the economic cost of achieving the goal of universal access to information society for each location $\mathrm{j}$ : EC. The economic cost refers to the investment of assets and to the operational expenditure in information exchanges and communications required to reach the poverty line location. The advantage of converting the indicators into economic costs of access for each location is that the estimate of such costs forces us to consider geographical differences of distinct locations. That is, the economic cost of access would equal the global indicator of capabilities, adjusted by the differences, and it would also be more accurate ${ }^{21}$, permitting the desired aggregation.

\footnotetext{
${ }^{21}$ In Sen's own words, for the relationship between income and capabilities, we have come to the following conclusion (Nussbaum and Sen, 1996, pg.69): "Therefore, the most accurate characterization of poverty as a lack of basic capabilities, from the point of view of the cause, can also be made in the most traditional format based on adequate income. The difference in the formulation is not relevant. What matters is to take note of the interpersonal and intersectorial variations between income and capabilities. This is the special contribution of the capability approach in the analysis of poverty."
} 
The following equation summarizes the measurement of the information and communication poverty:

$$
\mathrm{EC}=\mathrm{F}\left(\mathrm{CAP}_{0}^{\mathrm{i}}, \mathrm{LC}, \mathrm{TC}, \mathrm{UCj}\right)
$$

Where:

$\mathrm{EC}^{\mathrm{j}}=$ Economic cost of location $\mathrm{j}$ to reach the poverty line location. It includes the cost of investment in assets and the operational expenditure in exchange of information and ideas.

$\mathrm{CAP}_{0}{ }_{0}=$ Minimum capabilities that define the poverty line location, consistent with equation (1). It includes the indicators for ownership and capability to use assets, and the indicators for capabilities of exchange of information and ideas.

LC $=$ Local Constraints of location $\mathrm{j}$. It is the set of characteristics of location $\mathrm{j}$ based on structural restrictions that hinder its access to the information society.

$\mathrm{TC}^{\mathrm{j}}=$ Technological Constraints of location $\mathrm{j}$. It is the set of characteristics that determine the space of possible technological solutions, given the state of local technology and infrastructure.

$\mathrm{UC}^{\mathrm{j}}=$ ICT Usage Constraints of location $\mathrm{j}$. It is the set of characteristics unique to ICT management, given the local capabilities.

$\mathrm{F}=$ Function that transforms the characteristics of the poverty line location dependent on local, technology and usage restrictions into economic costs.

With the economic cost of access for each location, and provided that the economic cost of the poverty line location is zero, the aggregated measurements of the information and communication poverty can be calculated and its magnitude and depth can be identified. Existing methods as those of Foster-Greer-Thorbecke (FGT) and Sen-Shorrocks-Thon (SST), can be used the only difference being that they would be applied to geographic locations instead of households.

\section{CURRENT LOCAL CAPABILITIES (CAP)}

Understanding the current information and communication capabilities (initial situation) of each location under study would allow us to identify which would be considered by society as the poverty line location. In addition, it would let us identify the "distance" from the other location to the poverty line location in order to estimate the cost of reaching it. Which information, consistent with Table 1 , should be required for this purpose? Table 2 shows a summary of this information, including basic capabilities to use physical, human, economic and social assets and the capability to exchange 


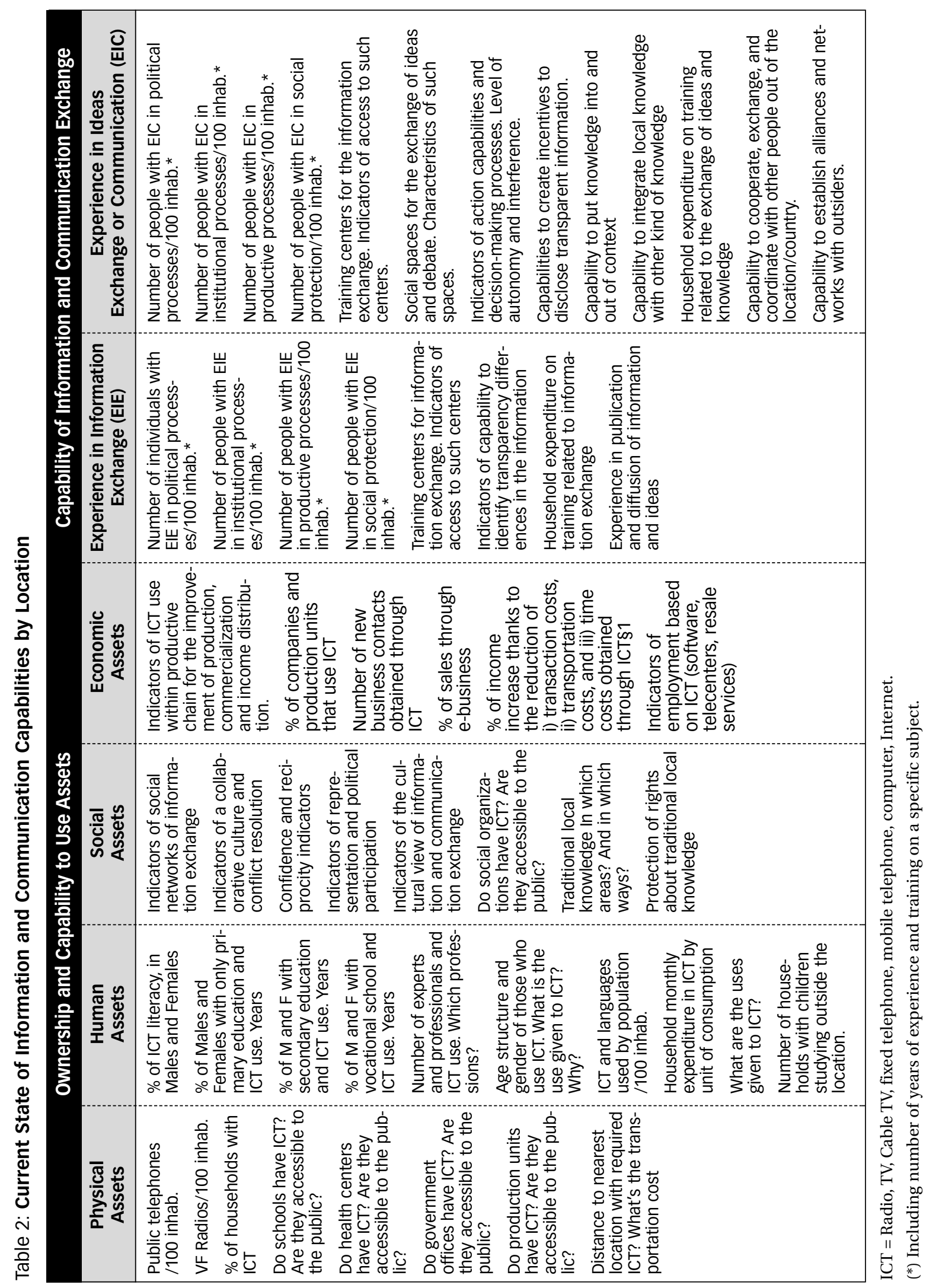


information and ideas which shall significantly affect the required economic cost to reach the poverty line location. This exchange of information and ideas must be transparent, contrary to asymmetrical information. The latter increases transaction costs, uncertainty, risk, and legal costs, resulting in suboptimal decisions for the economic agents. It is the opposite of having the information disclosed and provided in the amount and quality required, flowing without limitations. New ICT, in the framework of the construction of the information society, may contribute to reducing information costs and the asymmetry of information. ICT would not only have impact on production, consumption and exchange, but also on social, cultural and political aspects.

\section{LOCAL CONSTRAINTS (LC)}

Local structural restrictions are a group of economic, demographic, social and geographical characteristics that determine rural poverty and its reproduction, as shown

Table 3: Local Structural Constraints

\begin{tabular}{|c|c|c|c|}
\hline $\begin{array}{c}\text { Economic } \\
\text { Characteristics }\end{array}$ & $\begin{array}{l}\text { Demographic } \\
\text { Characteristics }\end{array}$ & $\begin{array}{c}\text { Social } \\
\text { Characteristics }\end{array}$ & $\begin{array}{c}\text { Geographic } \\
\text { Characteristics }\end{array}$ \\
\hline $\begin{array}{l}\text { Level of extreme poverty } \\
\text { which represents a great } \\
\text { restriction for payment } \\
\text { capacity } \\
\text { Access to production } \\
\text { Basic services } \\
\text { (electricity and water) } \\
\text { Quality of employment } \\
\text { and rate of unemployment } \\
\text { Structure of household } \\
\text { income } \\
\text { Structure of household } \\
\text { expenditure } \\
\text { Ownership and } \\
\text { productivity of assets } \\
\text { Basic services of electrici- } \\
\text { ty, water, gas, housing } \\
\text { quality and equipment } \\
\text { Production destined to } \\
\text { self-consumption, to } \\
\text { internal and external } \\
\text { markets } \\
\text { Economic, gender and } \\
\text { ethnic inequalities } \\
\text { Government offices and } \\
\text { services offered } \\
\text { Number of production } \\
\text { units; activities and } \\
\text { characteristics }\end{array}$ & $\begin{array}{l}\text { Population size and } \\
\text { density } \\
\text { Fertility and mortality } \\
\text { rates } \\
\text { Population structure } \\
\text { by age and gender } \\
\text { Migratory } \\
\text { characteristics } \\
\text { Registered and } \\
\text { documented population } \\
\text { Mother language and } \\
\text { most spoken languages } \\
\text { Number and size of } \\
\text { households } \\
\text { Responsible members } \\
\text { of the household } \\
\text { Literacy rate, school } \\
\text { attendance, educational } \\
\text { level, years of study } \\
\text { Handicapped population }\end{array}$ & $\begin{array}{l}\text { Health and access to } \\
\text { health services } \\
\text { Education and access } \\
\text { to educational services } \\
\text { Availability of rules and } \\
\text { internal and external } \\
\text { social networks } \\
\text { Ability of self help and } \\
\text { cooperation } \\
\text { Indicators of social } \\
\text { mobility } \\
\text { Number of schools, } \\
\text { up to which grade } \\
\text { Number of health } \\
\text { centers, and services } \\
\text { offered. } \\
\text { Indicators of local rules, } \\
\text { of legal and civic } \\
\text { protection } \\
\text { Number of social } \\
\text { organizations; activities } \\
\text { and characteristics }\end{array}$ & $\begin{array}{l}\text { Geographical, weather } \\
\text { and environmental } \\
\text { characteristics } \\
\text { Level of geographical } \\
\text { isolation } \\
\text { Availability and quality } \\
\text { of roads } \\
\text { Availability and quality of } \\
\text { transportation means } \\
\text { Usual means of } \\
\text { transport } \\
\text { Distance and time of } \\
\text { transport to markets, } \\
\text { health, educational, and } \\
\text { management centers. }\end{array}$ \\
\hline
\end{tabular}


in Table 3. These restrictions may be mitigated by the benefits of access to the information society.

\section{USAGE CONSTRAINTS (UC)}

Structural usage constraints are a group of internal factors of ICT, related to connectivity, content, training, and sustainability, as shown in Table 4.

Table 4: Structural Constraints to ICT Use

\begin{tabular}{|c|c|c|c|}
\hline Connectivity & Content & Training & Sustainability \\
\hline $\begin{array}{l}\text { High connectivity costs } \\
\text { High costs of Internet use } \\
\text { in rural areas } \\
\text { Problems of equipment } \\
\text { installation } \\
\text { Problems of equipment } \\
\text { and software } \\
\text { maintenance }\end{array}$ & $\begin{array}{l}\text { Lack of local and } \\
\text { relevant contents } \\
\text { Academic level of the } \\
\text { content, with little } \\
\text { applicability to the } \\
\text { reality of the poor } \\
\text { Language problems } \\
\text { (high percentage of } \\
\text { content in English) }\end{array}$ & $\begin{array}{l}\text { Lack of human } \\
\text { capability to use ICT } \\
\text { Literacy is a } \\
\text { requirement for use } \\
\text { Permanent changes in } \\
\text { software requires } \\
\text { continuous training } \\
\text { Tools' design is based on } \\
\text { the needs of urban users }\end{array}$ & $\begin{array}{l}\text { Need of a users' network } \\
\text { (scale effects of invest- } \\
\text { ment in } \\
\text { infrastructure) } \\
\text { Need of human } \\
\text { capability for the proper } \\
\text { management of ICT }\end{array}$ \\
\hline
\end{tabular}

\section{TECHNOLOGICAL CONSTRAINTS (TC)}

Technology has peculiar characteristics that may mean restrictions or opportunities, depending on the incentives or disincentives generated for the demand and supply, as shown in Table 5.

Table 5: Technological Opportunities and Constraints

\begin{tabular}{|c|c|}
\hline Demand's point of view & Supply's point of view \\
\hline $\begin{array}{l}\text { Economies of strategic complementarity, } \\
\text { compatibility and standards, consumption } \\
\text { external factors and substitution and lock-in costs, } \\
\text { typical of markets characterized by network } \\
\text { economies (Shy, 2001; Shapiro and Varian, 1999). } \\
\text { In many cases, it implies very high and continuous } \\
\text { costs for developing countries. } \\
\text { Strategies of discrimination due to delay in } \\
\text { dissemination of information, quality discrimination, } \\
\text { production of new versions, renting before sale and } \\
\text { production of different versions (Shy, 2001). } \\
\text { Coexistence, flexibility and technological } \\
\text { convergence that allow for a variety of technological } \\
\text { solutions, for every need and circumstance. } \\
\text { This is an opportunity. } \\
\text { Adaptation of problems of technologies designed for } \\
\text { developed countries to the realities of developing } \\
\text { countries. }\end{array}$ & $\begin{array}{l}\text { Production conditions characterized by scale } \\
\text { economies. } \\
\text { High level of technological innovation on data trans- } \\
\text { mission and technological convergence demand } \\
\text { continuous and significant investments. } \\
\text { High fixed and sunk costs of information } \\
\text { production, and at the same time, additional costs of } \\
\text { reproduction and distribution almost null. } \\
\text { Competition limited to few operators can give rise to } \\
\text { the exercise of market power. It favors the operator. }\end{array}$ \\
\hline
\end{tabular}




\section{Conclusions and Some Implications}

From the methodological point of view, the poverty line location approach to the measurement of information and communication poverty introduced in this paper, departs from mainstream international development practice in three aspects. Firstly, the pro-poor approach is treated as a priority compared to the pro-competitiveness approach. Secondly, comparisons are made between different locations in the same country, instead of comparisons between countries. This contributes to identifying the problem more accurately inside each country in order to design public policies according to the country's own realities and restrictions. Thirdly, the economic cost is measured to reach the poverty line location. This offers more accurate information for drafting public policy, which goes beyond the mere presentation of connectivity and usage indicators.

In conceptual terms, the approach of information and communication poverty contributes to the understanding that information and communication are essential for the advancement of human freedoms, as stated by Sen. Thus, besides the need to strengthen the poor's capabilities for the ownership and use of economic assets, there are new capabilities for the exchange of information and ideas about the economy, politics and society.

This approach also emphasizes that information and communication are a variable included in a group of interdependent variables related to the general issue of poverty. The success of achieving the minimum capability to participate in the information society depends on and, at the same time, affects other critical aspects of poverty such as education, health care, social networks, productivity and political participation.

Another important issue resulting from this approach is the need to acknowledge structural restrictions. Many restrictions act against, and others favor the adoption of new information and communication capabilities. However, the adoption contributes, at the same time, to mitigating the negative structural restrictions.

From the point of view of public policy, the information and communication poverty measurement carried out by the establishment of a poverty line location, introduces the need to consider three new issues. First, it opens the discussion on what the poverty line location should be according to the realities of a society. Second, it informs on the magnitude and depth of such poverty, location by location, and aggregately, by indicators translated into the economic cost of reducing poverty. Third, it necessarily opens the discussion on the identification of incentives and restrictions (financial, institutional, organizational and technological) for a real participation by rural communities, markets and governments in a policy design to reduce the information and communication poverty. 


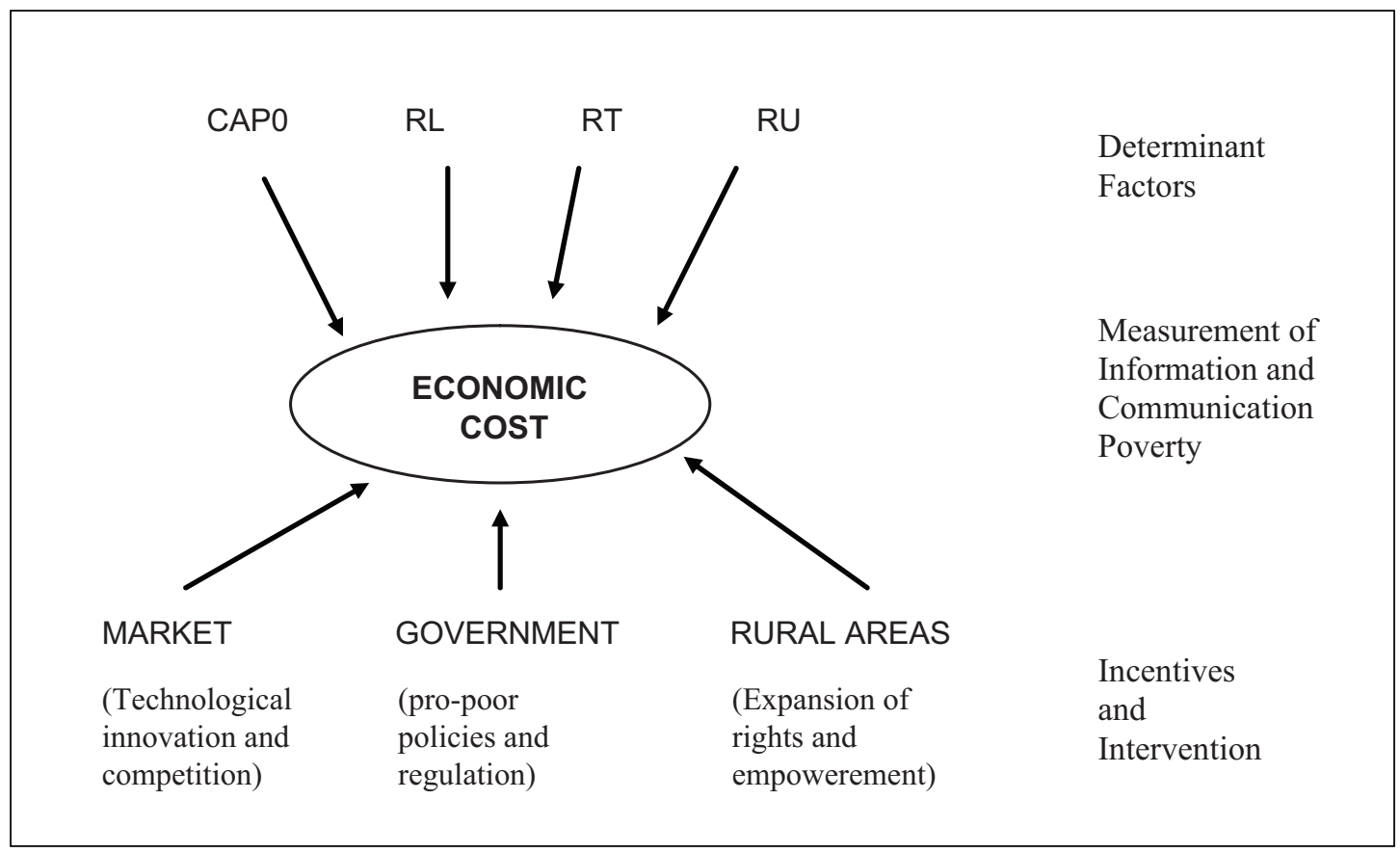

In terms of incentives and restrictions for participation by households and organizations in rural communities, the self help and empowerment level depend on practical outcomes of the information and communication exchange over the reduction of structural restrictions and the release of new capabilities.

In terms of incentives and restrictions for market's participation, despite the great advances in technological innovations, reduction of costs, competition and coverage, as well as the advances in regulation, the performance of the market and the private telecommunications and information supply tend to divide population by two: those who have a willingness to pay equal or higher prices than the market's price and those who have a willingness to pay a lower price. The market also tends to divide the population into two geographical areas; market coverage is reduced to urban areas and rural locations where investment can be profitably recovered. A free market will not supply the service in urban areas and rural locations where profitability cannot be ensured. This consequence causes concern, particularly in countries with low levels of economic and human development and a high level of social inequality, typical of Latin American societies, where an important part of the population has low willingness to pay and lives in not-profitable urban areas or rural locations.

In terms of incentives and restrictions to participation by the government the acknowledgment that participation in the information society is a public good and 
the prospects that the social benefits are higher than social costs usually contributes to justify government's intervention through pro-poor policies specifically targeted at reducing the information and communication poverty. In practice, implemented policies have typically been called policies of universal access/service aiming at extending the coverage of telecommunication services beyond the market. These policies generally include private participation, based on subsidies to investment and, in some cases, on subsidies to operations. Universal access via subsidies is possible. Diverse technological solutions can be designed as well as geographical areas of concession identified by merging profitable and non profitable locations in order to minimize subsidies. Not all countries have achieved the implementation of universal access programs as they are very demanding in terms of institutional and organizational ability, in addition to financial restrictions. When national government programs fail, non governmental solutions arise. They are usually more flexible and effective, although they may also be more expensive (duplication of efforts, errors, and investments), isolated, and of limited impact. 


\section{References}

Attanasio, O. \& Székely, M. (1999). An Asset-Based Approach to the Analysis of Poverty in Latin America. Mimeo.

Bourguignon, F. (2000). The Pace of Economic Growth and Poverty Reduction. Paris: The World Bank and Delta. Mimeo.

Chambers, R. (1997a). Who's Reality Counts: Putting the Last First. London: Intermediate Technology Publications.

Cherry, B.A. \& Wildman, S. (1999). Conceptualizing Universal Service: Definitions, context, social process and politics. In Cherry, B.A., Wildman, S. and Hammond, A. (Editors). Making Universal Service Policy: Enhancing the Process through a Multidisciplinary Evaluation. Mahwah: Lawrence Erlbaum Associates Publishers.

Dollar, D. \& Kraay, A. (2000). Growth is Good for the Poor. Development Research Group. The World Bank. Mimeo.

Easterly, W. (2003). Search of Growth: Wanderings and Tribulations of Development Economists. Spanish Edition. Barcelona: Antoni Bosch.

Foster, J., Greer, J. \& Thorbecke, E. (1984). A Class of Decomposable Poverty Measures. Econometrica, 52 (3), 761-766.

Gigler, B. S. (2001). Empowerment through the Internet: Opportunities and Challenges for Indigenous Peoples. In: Technology for Social Action. TechKnowLogia, July/August.

Gigler, B.S. (2005). Enacting and interpreting technology from usage to well-being: Experiences of indigenous peoples with ICT. In Rahman, H., Empowering Marginal Communities with Information Networking. Idea Group.

Kenny, C. (2003). Development's False Divid-Giving Internet Access to the World's Poorest Will Cost a Lot and Accomplish Little. Foreign Policy, Jan.-Feb., 76-77.

Lora, E., Pagés, C., Panizza, U \& Stein, E. (2004). A Decade of Development Thinking. Research Department. Washington, D.C.: Inter-American Development Bank.

McNamara, K.S. (2000). Why Wired? The Importance of Access to Information and Communication Technologies. International Journal of Technologies for the Advance of Knowledge and Learning, March/April.

McNamara, K. S. (2003). Information and Communication Technologies, Poverty and Development: Learning from Experience. A Background paper for the InfoDev Annual Symposium. Washington, D.C.: The World Bank.

Nelson, N. \& Wright, S. (1995). Participation and Power, in: Nelson and Wright (Editors). Power and Participatory Practice. London: IT.

Ravallion, M. (2000). Growth and Poverty: Making Sense of the Current Debate. Mimeo. Washington DC: The World Bank.

Robeyns, I. (2004). Assessing Global Poverty and Inequality: Income, Resources and Capabilities. Preprint Article. Metaphilosophy LLC and Blackwell Publishers.

Sen, A. (1995). Markets and Freedoms: Achievements and Limitations of the Market Mechanism in Promoting Individual Freedoms. In New Welfare Economy Selected Writing. Valencia: University of Valencia.

Sen, A. (1996). Capability and Welfare in the Quality of Life. Nussbaum, M. \& Sen, A. Compilers. Spanish Edition. Mexico: Fondo de Cultura Económica.

Sen, A. (2000). Development and Freedom. Spanish Edition. Argentina: Editorial Planeta. 
Shapiro, C. \& Varian, H. (1999). The Information Domain: An Strategic Guide for Network Economics. Spanish Edition. Barcelona: Antoni Bosh.

Shy, O. (2001). The Economics of Networks Industries. Cambridge, UK: Cambridge University Press.

Székely, M. (2001). Where to from here? Generating Capabilities and Creating Opportunities for the Poor. Research Network Working paper R-431. Washington, D.C.: Inter-American Development Bank.

Orbicom. (2003). Monitoring the Digital Divide and Beyond. Sciadas, G. (Editor). Claude-Yves Charron Publisher. Ottawa: NRC Press.

World Bank Institute. (2005). Poverty Manual. [Electronic Version]. The World Bank Group.

World Economic Forum. (2004). Global Information Technology Report 2003-2004. 